Jurnal Basicedu Volume 4 Nomor 2 April 2020 Hal.257-267

JURNAL BASICEDU

Research \& Learning in Elementary Education

https://jbasic.org/index.php/basicedu

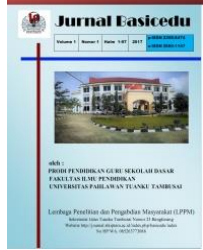

\title{
EFEKTIVITAS PENGGUNAAN MODEL PROBLEM BASED LEARNING DAN MODEL GROUP INVESTIGATION TERHADAP KEMAMPUAN KERJASAMA SISWA SEKOLAH DASAR
}

\author{
Bernadetha Titis Wulan Sari ${ }^{1}$, Firosalia Kristin ${ }^{2}$ \\ Universitas Kristen Satya Wacana, Jawa Tengah, Indonesia ${ }^{1,2}$ \\ E-mail: bernadethatitis@gmail.com ${ }^{1}, \underline{\text { firosalia.kristin@ } \mathrm{uksw}_{\text {.edu }}{ }^{2}}$
}

\begin{abstract}
Abstrak
Penelitian ini bertujuan untuk mengetahui efektifitas penerapan model PBL dan model GI terhadap kemampuan kerjasama siswa pada pembelajaran IPA SD Negeri Panjang 03 Ambarawa. Jenis penelitian ini adalah penelitian eksperimen. Subjek pada penelitian ini adalah siswa kelas 4 SD Negeri Panjang 03 yang berjumlah 53, yang terbagi atas kelas eksperimen berjumlah 27 siswa dan kelas kontrol berjumlah 26 siswa. Teknik pengumpulan data yang digunakan dalam penelitian ini adalah observasi untuk mengetahui kemampuan kerjasama siswa dan studi dokumentasi. Teknik analisis data dengan analisis deskriptif dan analisis inferensial dengan menggunakan bantuan software SPSS versi 25 for windows. Berdasarkan uji t yang telah dilakukan data memiliki nilai signifikansi 0,000 yang artinya kurang dari 0,05 , sehingga $\mathrm{H}_{\mathrm{o}}$ ditolak dan $\mathrm{H}_{\mathrm{a}}$ diterima, artinya kemampuan kerajasama menggunakan model PBL lebih unggul secara signifikan dibandingkan dengan model GI. Perbedaan kedua model tersebut terlihat dari rerata kedua kelas, pada kelas eksperimen memiliki rerata 83,33 sedangkan kelas kontrol memiliki rerata 71,50, sehingga dapat disimpulkan terdapat perbedaan efektivitas kemampuan kerjasama siswa muatan pelajaran IPA kelas 4 dengan menggunakan model Problem Based Learning dan Group Investigation SD Negeri Panjang 03 Ambarawa.
\end{abstract}

Kata Kunci: problem based learning, group investigation, kerjasama, IPA

\begin{abstract}
The purpose of this research is to know about effectiviness of the application PBL and GI model student's ability to collaborate in learning science at Negeri Panjang 03 elementary school in Ambarawa. The type of this research is experimental research. The subjects in this research are students grade 04 of Negeri Panjang 03 Elementary School with 53 totaling students, which were devided into 27 students from experimental class and 26 from the control class. The data collection technique used in this reseach is observation to determine student's ability to collaborate and documentation study. The analysis data techniques are descriptive analysis and inferential analysis using SPPS 25 for windows. Based on the T-Test, the data has a significance of 0,000 which means less than 0,05 , so that $\mathrm{H}_{\mathrm{o}}$ is reject and $\mathrm{H}_{\mathrm{a}}$ is accept, the meaning of ability cooperation using PBL model is significantly compared than GI model. The difference between the two models can seen from the average of two class, the experimental class has an average 83,33 while the control class has 71,50. So , that's can be concluded is a difference in the effectiviness of student's collaborative abililty of grade 4 that using Problem Based Learning model and Group Investigation at Negeri Panjang 03 Ambarawa.
\end{abstract}

Keywords: problem based learning, group investigation, collaborative, Science

@ Jurnal Basicedu Prodi PGSD FIP UPTT 2020

$\triangle$ Corresponding author :

Address :-

ISSN 2580-3735 (Media Cetak)

Email :-

ISSN 2580-1147 (Media Online)

Phone :- 


\section{PENDAHULUAN}

Perkembangan manusia dan teknologi yang sangat pesat di zaman sekarang ini, diperlukan sesuatu hal yang mendukung untuk suatu bangsa menjadi maju. Suatu bangsa tidak akan maju jika tidak mampu meningkatkan kualitas sumber daya manusia yang dimiliki. Seperti halnya dalam bidang pendidikan, pendidikan memiliki peran yang besar untuk membentuk siswa menjadi manusia yang berkualitas. Pendidikan merupakan suatu usaha untuk mewujudkan suasana belajar dan proses pembelajaran sehingga seseorang memiliki kekuatan spiritual dan akhlak mulia, kepribadian, kecerdasan, dan kemampuan. Berbicara pendidikan tidak terlepas dari proses pembelajaran yang terdapat di dalam kelas.

Proses pembelajaran yang saat ini diterapkan oleh tenaga pendidik kebanyakan masih melihat bahwa target kurikulum menjadikan hal utama pencapaian dalam suatu pembelajaran, yang pada akhirnya pembelajaran hanya bersifat menghafalkan konsep bukan pada pemahaman konsep. Pelaksanaan kegiatan pembelajaran yang diterapkan di Sekolah Dasar pada umumnya masih menekankan aspek pengetahuan tanpa melibatkan secara aktif siswa dalam proses pembelajaran (Kristin F, 2015: 47). Terlihat selama pembelajaran bahwa yang lebih dominan adalah guru. Biasanya guru dalam menyampaikan materi menggunakan metode ceramah, sehingga tercipta suasana yang kurang aktif yaitu dengan siswa hanya duduk dan mendengarkan apa yang disampaikan oleh guru, tidak jarang kesempatan untuk bertanya hanya memiliki sedikit peluang. Dengan demikian akan tercipta suasana belajar yang tidak kondusif dan pasif.

Keberhasilan siswa tidak terlepas dari berbagai faktor yang mempengaruhi. Salah satunya bahwa hakikatnya manusia adalah makhluk sosial dimana manusia dalam memenuhi segala kebutuhan dan mencapai tujuan hidupnya memerlukan bantuan orang lain, sehingga sikap atau kemampuan kerjasama harus dimiliki oleh sesorang di lingkungan rumah, sekolah, dan masyarakat. Kerjasama dapat dikatakan sebagai kegiatan yang dilakukan secara bersama-sama untuk mencapai tujuan bersama. Kerjasama merupakan suatu tindakan, usaha atau sikap ingin bekerjasama dengan orang lain sehingga dapat mencapai tujuan yang telah dtetukan bersama (Samini, 2012:118). Kerjasama jika dilakukan dengan saling terbuka, saling mengerti satu sama lain, dan semua ikut ambil bagian didalamnya akan tercipta kerjasama yang efektif dan lancar. Kebiasaan untuk bersama dan bekerjasama, saling mengahargai, menerima, dan memberi perlu ditumbuhkembangkan di sekolah terutama dalam proses belajar (Rosita dkk, 2013: 5).

Kemampuan kerjasama dapat digunakan pada muatan pelajaran Ilmu Pengetahuan Alam (IPA). IPA memberikan kesempatan untuk memupuk rasa ingin tahu siswa terhadap berbagai hal secara alamiah (Samatowa, 2011: 2 ). IPA juga dapat memfasilitasi siswa sehingga dapat berinteraksi dengan alam dan mengenal berbagai fenomenafenomena alam yang tak terlepas dari kehidupan siswa. Pelajaran IPA tidak terlepas dari pengalaman yang diperoleh secara sendiri. Pengalaman tersebut di dapat melalui proses belajar langsung atau terjun langsung ke lapangan. Tidak hanya secara sendiri siswa mampu memeproleh pengalaman tersebut, diperlukan kerjasama dengan orang lain sehingga pengalaman yang didapat dapat beragam dan memperkaya siswa dengan hal-hal baru yang belum diketahui sebelumnya.

Berdasarkan observasi awal yang dilakukan di SD Negeri Panjang 03, masih kurang hal kerjasama saat melakukan kerja kelompok. Terlihat saat melalukan pembagian kelompok masih terdapat beberapa siswa yang mengeluh dengan teman satu kelompoknya mereka hanya ingin bergabung dengan teman dekatnya. Selain itu, pada saat dibentuk dengan 1 kelompok 
berisikan 5 siswa terdapat beberapa kelompok yang anggotanya tidak ambil bagian dalam berdiskusi dan mengerjakan tugas kelompok, mereka lebih pada melaksanakan kegiatannya sendiri seperti bermain, mengganggu teman dalam kelompok dan berbicara membahas diluar materi yang sedang dibahas.

Menyikapi hal tersebut, peneliti menawarkan suatu model pembelajaran yang diharapkan dapat membantu siswa dalam meningkatkan kerjasama di dalam kelas yaitu dengan model Problem Based Learning (PBL). PBL adalah suatu proses pembelajaran yang diperoleh melalui pemahaman akan suatu masalah dan sistematik penyelesaian masalah tersebut (Huda, 2013:271). Model PBL dapat dilaksanakan dalam kelompok-kelompok kecil atau secara individu. Kegiatan menggunakan model PBL diawali dengan guru mengorientasikan siswa pada suatu permasalahan selanjutnya siswa dibimbing untuk melakukan penelitian mengenai metode atau cara yang tepat untuk menyelesaikan permasalahan yang telah disajikan. Model pembelajaran PBL merupakan inovasi dalam pembelajaran karena siswa mampu berpikir dengan optimal melalui proses kerjasama kelompok yang sistematis, sehingga siswa dapat mengembangkan kemampuan berpikirnya secara berkesinambungan. Selain, model Problem Based Learning terdapat model Group Investigation. Model Group Investigation merupakan pembelajaran bersifat kelompok yang memerlukan kemampuan berpikir tinggi (Huda, 2013:292). Pada dasarnya, pembelajaran menggunakan model GI menekankan pada heterogenitas dan kerjasama antarsiswa. Siswa akan ikut memilih topik yang akan dipelajari selain itu menginvestigasi topik tersebut dan pada akhirnya menyajikan suatu laporan kepada siswa yang lainnya. Terlihat dari sintaks kedua model tersebut, model $P B L$ dan $G I$ mempunyai beberapa persamaan. Kedua model tersebut sama-sama bersifat inovatif dan siswa terlibat langsung didalamnya. Selain itu, bekerjasama sangat terlihat pada kegiatan siswa saat pembelajaran menggunakan kedua model tersebut.

Penelitian yang dilakukan oleh Dimas Anjar tahun 2019, berjudul "Perbedaan Efektivitas Group Investigation Dengan Problem Based Learning Terhadap Kerjasama Siswa Mata Pelajaran IPA Siswa Kelas 5 SD Gugus Joko Tingkir" menyimpulkan adanya perbedaan yang signifikan dari hasil kerjasama IPA. Hasil kerjasama menggunakan model GI memiliki rerata sebesar 100,65 sementara itu rerata dari hasil kerjasama penerapan model PBL sebesar 93,81. Dengan demikian, perlakukan pembelajaran menggunakan model GI memberi dampak hasil kerjasama yang tinggi dibandingkan dengan menggunkan model PBL ( Anjar, 2019:1).

Penelitian selanjutnya dilakukan Intan Restu Agustri pada tahun 2018. Menyebutkan bahwa pembelajaran menggunakan model Problem Based Learning pada kemampuan kerjasama menghasilkan peningkatan. Pada siklus I terdapat sebanyak $41 \%$, lalu di siklus II sebesar $74 \%$, sedangkan pada siklus III sebesar $83 \%$. Terlihat bahwa terdapat peningkatan setelah menggunakan model Problem Based Learning (Restu, 2018:1).

Penelitian yang dilakukan oleh Ika Rahayu dan Irna Yulistiani menyebutkan bahwa penerapan model Problem Based Learning dapat meningkatkan sikap kerjasama dan hasil belajar siswa kelas IV SDN Kencana Indah 2 Kecamatan Rancaekek Kabupaten Bandung tema 1 indahnya kebersamaan subtema 1 keberagaman budaya bangsaku. Terlihat bahwa pada siklus I sikap kerjasama elum terlihat sehingga memiliki persentase $57,7 \%$, selanjutnya pada sikulus II pada kategori sudah membudaya mencapai 93,9\% (Rahayu, 2016: 1 ).

Penelitian yang dilakukan Upik Dwi Fitrianingsih, Ahmad Nashir Tsalatsa, dan Mei Fita Asri Untari tentang keefektifan model pembelajaran group investigation terhadap hasil 
belajar materi sumber daya alam kelas IV SD Negeri Puri 03 Pati. Berdasarkan uji-t diperoleh t hitung lebih besar t tabel yaitu 8,699 > 2,059, yang berarti Ho ditolak dan $\mathrm{Ha}$ diterima. Dapat disimpulkan bahwa ada perbedaan hasil belajar siswa sebelum dan sesudah perlakuan. (Fitrianingsih dkk, 2019: 1 ).

Berpijak dari hasil penelitian sebelumnya menimbulkan keragu-raguan bagi peneliti. Berhubungan dengan hal tersebut peneliti bermaksud untuk ikut serta dalam memberikan partisipasi membuktikan kedua model tersebut melalui kegiatan penelitian yang berjudul "Efektivitas penggunaan Model Problem Based Learning dan Model Group Investigation Terhadap Kemampuan Kerjasama Siswa Kelas 4 Muatan Pelajaran IPA"

\section{METODE}

Penelitian ini menggunakan jenis penelitian eksperimen kuasi atau eksperimen semu. Menurut (Slameto, 2015:139) eksperimen kuasi adalah penelitian yang mendekati eksperimen sebenarnya, namun peneliti tidak dapat mengontrol semua variable yang terdapat didalamnya hanya dapat mengkontrol variable yang berpengaruh pada penelitiannya saja. Penelitian ini bertujuan untuk mengetahui ada tidaknya pengaruh tertentu terhadap kelas eksperimen dan kelas kontrol. Kelas eksperimen diberikan perlakuan dengan model Problem Based Learning dan kelas control diberikan perlakuan dengan model Group Investigation. Penelitian ini menggunakan desain Nonequivalent Control Grup Design, yaitu membandingkan dua kelompok yaitu kelompok eksperimen dan kontrol.
Tabel 1

Nonequivalent Control Group Design (Sugiyono

\begin{tabular}{|c|c|c|c|}
\hline Kelompok & Pretest & $\begin{array}{c}\text { Variabel } \\
\text { Bebas }\end{array}$ & Posttest \\
\hline Eksperimen & $\mathrm{O}_{\mathrm{e}}$ & $\mathrm{X}_{1}$ & $\mathrm{P}_{\mathrm{e}}$ \\
\hline Kontrol & $\mathrm{O}_{\mathrm{k}}$ & $\mathrm{X}_{2}$ & $\mathrm{P}_{\mathrm{k}}$ \\
\hline
\end{tabular}

Terdapat empat kelompok data dalam desain penelitian ini yaitu kelompok eksperimen dan kelompok kontrol, pretest kelompok eksperimen $\left(\mathrm{O}_{\mathrm{e}}\right)$ dan pretest kelompok kontrol $\left(\mathrm{O}_{\mathrm{k}}\right)$, sedangkan untuk data posttest kelompok eksperimen $\left(\mathrm{P}_{\mathrm{e}}\right)$ dan data posttest kelompok kontrol $\left(\mathrm{P}_{\mathrm{k}}\right)$.

Penelitian ini mengambil populasi dari seluruh kelas 4 Gugus Palagan yang terletak di Kecamatan Ambarawa. Sampel yang dipilih untuk melakukan penelitian adalah SD Negeri Panjang 03, Ambarawa. Subjek penelitian pada kelas eksperimen adalah 27 siswa, sedangkan kelas kontrol adalah 26 siswa. Variabel pada penelitian ini dibagi menjadi dua yaitu variable bebas atau independent yang dapat disimbolkan X, sedangkan untuk variabel terikat atau dependent dapat disimbolkan Y. Variabel bebas pada penelitian ini adalah model pembelajaran Problem Based Learning dan Group Investigation.

Teknik pengumpulan data yang digunakan dalam penelitian ini adalah observasi dan studi dokumentasi. Observasi digunakan untuk menilai kemampuan kerjasama dalam pelaksanaan pembelajaran menggunakan model Problem Based Learning dan Group Investigation. Selama melakukan observasi, siswa akan dinilai menggunakan lembar observasi kemampuan kerjasama siswa. Lembar observasi kemampuan kerjasama memiliki 25 butir pernyataan di dalamnya. Setiap pernyataan terdapat skor 1 sampai 4 sesuai dengan skala likert, pada skor $1=$ Tidak Pernah, skor 2 = Jarang, 3 = Kadangkadang, 4 = Sering. Lembar penilaian kemampuan kerjasama diberikan kepada observer diminta untuk memberikan tanda centang $(\sqrt{ })$ pada setiap 
pernyataan sesuai skor yang diberikan. Pengumpulan data juga dilakukan dengan studi dokumentasi untuk memperoleh data awal berupa daftar siswa, nama siswa, dan dokumentasi foto selama proses penelitian.

Instrumen penilaian kemampuan kerjasama sebelum diberikan pada kelas eksperimen dan kontrol, maka diuji kevalidan dengan cara uji pakar. Hasil uji pakar diperoleh sebesar 96\% yang artinya masuk dalam kategori sangat tinggi. Selanjutnya instrumen tersebut diuji reliabilitas yaitu sebesar 0,739 yang masuk dalam kategori reliabel. Teknik Analisis data dianalisis dengan analisis deskriptif berupa skor minimal, skor maksimal, rata-rata, dan standar devisiasi. Selajutnya dilakukan analisis inferensial yaitu uji normalitas, uji homogenitas, dan uji t untuk mengetahui perbedaan hasil skor penilaian kemampuan kerjasama pada kelas eksperimen dan kelas kontrol.

\section{HASIL DAN PEMBAHASAN}

Lembar observasi penilaian kerjasama diisi oleh observer dengan memberikan skor 1-4. Indikator yang terdapat pada lembar observasi penilaian kemampuan kerjasama terdapat 5 indikator yaitu komunikasi, sumbangan ide, menghargai kontribusi, mendorong partisipasi, dan tidak mendominasi kelompok. Setiap pernyataan terdapat skor 1 sampai 4 sesuai dengan skala likert, yang setiap skor memiliki arti sebagai berikut: skor $1=$ Tidak Pernah (TP), skor $2=$ Jarang (JR), 3 = Kadang-kadang (KD), 4 = Sering (SR). Sebelum diberikan perlakuan pada kelas eksperimen dan kontrol dilakukan observasi dan penilaian kerjasama. Berikut merupakan diagram batang penyebaran data skor penilaian kemampuan kerjasama pada kelas eksperimen dan kelas kontrol sebelum diberikan perlakuan.

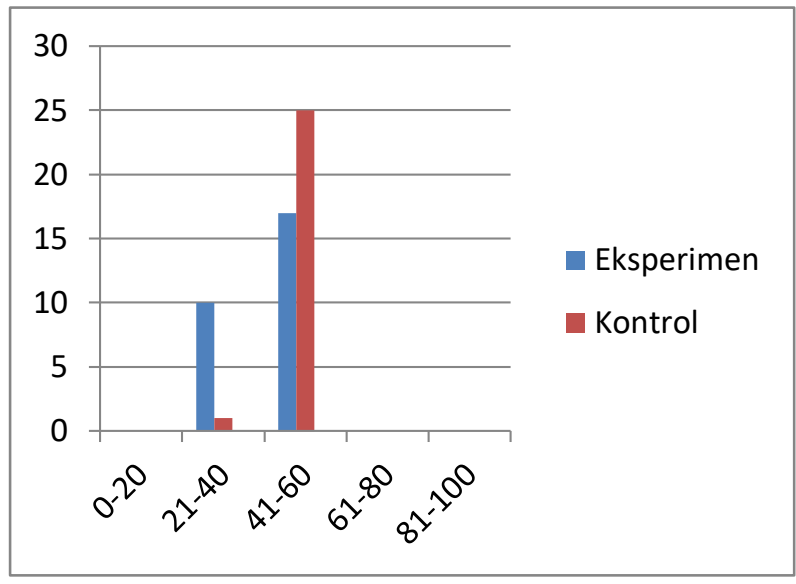

\section{Gambar 1}

Diagram Batang Penyebaran Data Skor Penilaian Kemampuan Kerjasama Kelas Eksperimen dan Kelas Kontrol (Pretest)

Berdasarkan diagram yang disajikan di atas, terlihat bahwa pada kelas eksperimen dari 27 siswa yang memiliki skor kemampuan kerjasama 21-40 adalah sebanyak 10 siswa dengan kategori rendah. Sedangkan yang memiliki skor 41-60 adalah sebanyak 17 siswa dengan kategori sedang. Selanjutnya pada kelas kontrol siswa yang memiliki skor kemampuan kerjasama 21-40 adalah sebanyak 1 orang dengan kategori rendah. Selanjutnya siswa yang mendapatkan skor 41-60 sebanyak 25 siswa dengan kategori sedang. Dari hasil yang telah dipaparkan terlihat bahwa pada kelas eksperimen dan kelas kontrol kemampuan kerjasama masih masuk dalam kategori rendah dan sedang.

Pada kelas eksperimen sebelum diberikan perlakuan pada indikator komunikasi dari 27 siswa yang dominan hanya 7 siswa. Selama diskusi berjalan masih banyak siswa yang kurang aktif berbicara mengenai materi yang dibahas dalam kelompok. Pada indikator sumbangan ide yang dominan hanya 2 siswa, terlihat bahwa selama diskusi berjalan siswa belum bisa memberikan dan menjelaskan ide kepada kelompok dengan jelas, logis, dan sistematis. Indikator menghargai kontribusi dari 27 siswa yang dominan hanya 3 siswa, selama diskusi berjalan banyak siswa yang 
belum mampu memperhatikan dan menghargai disaat anggota lainnya sedang berbicara atau menyampaikan pendapat. Bahkan terdapat beberapa siswa yang berpindah-pindah tempat dan bermain dengan kelompok lain. Pada indikator mendorong partisipasi terlihat bahwa terdapat 11 siswa yang dominan pada indikator mendorong partisispasi. Banyak siswa yang mendorong teman sekelompoknya untuk ikut serta dalam diskusi. Pada indikator tidak mendominasi kelompok terdapat 4 siswa yang dominan di indikator tersebut. Terlihat bahwa pengerjaan tugas kelompok masih dibebankan hanya pada 1 hingga 2 siswa saja dan tidak melibatkan semua anggota kelompok.

Pada kelas kontrol sebelum diberikan perlakuan pada indikator komunikasi dari 27 siswa yang dominan adalah 10 siswa. Terlihat bahwa selama diskusi berjalan siswa aktif berbicara mengenai materi dan bertanya pada siswa lain jika merasa kesulian dalam mengerjakan tugas kelompok. Pada indikator sumbangan ide terdapat 4 siswa yang dominan pada indikator ini, hanya sedikit siswa yang berani berpendapat dan menjelaskan pendapat tersebut dengan logis, jelas dan sistematis. Selanjutnya pada indikator menghargai kontribusi hanya terdapat 2 siswa yang dominan pada indikator tersebut. Terlihat bahwa selama diskusi banyak siswa yang masih bercanda dan tidak mendengarkan siswa yang sedang berpendapat. Pada indikator mendorong partisispasi dari 27 siswa terdapat 7 siswa yang dominan pada indikator tersebut. Siswa selama diskusi berjalan sebagaian mendorong anggota lain untuk berpartisipasi dalam kegiatan diskusi. Pada indikator tidak mendominasi kelompok hanya terdapat 3 siswa yang mendominasi. Pengerjaan tugas kelompok masih dibebankan pada beberapa siswa saja dan pembagian tugas kelompok tidak merata.
Setelah mengetahui bahwa pada kelas eksperimen dan kelas kontrol memiliki kemampuan kerjasama masuk dalam kategori rendah dan sedang. Maka peneliti memberikan perlakuan pada kelas eksperimen dan kelas kontrol dengan menggunakan model PBL dan GI sehingga siswa memiliki perubahan dalam kemampuan kerjasama. Pada kelas eksperimen terlihat bahwa setelah diberikan perlakuan menggunakan model Problem Based Learning, siswa yang memiliki skor kemampuan kerjasama 61 sampai dengan 80 adalah sebanyak 11 siswa yang masuk dalam kategori tinggi. Sedangkan siswa yang mendapat skor 81 sampai dengan 100 adalah sebanyak 16 siswa masuk dalam kategori sangat tinggi. Pada kelas kontrol setelah diberikan perlakuan menggunakan model Group Investigation, siswa yang memiliki skor 41 sampai dengan 60 adalah sebanyak 3 sehingga masuk dalam kategori sedang. Sedangkan untuk siswa yang memiliki skor 61 sampai dengan 80 adalah sebanyak 20 siswa dan masuk dalam kategori tinggi. Siswa yang memiliki skor 81 sampai dengan 100 adalah sebanyak 3 siswa sehingga masuk dalam kategori sangat tinggi. Berikut merupakan diagram batang penyebaran data skor penilaian kemampuan kerjasama pada kelas eksperimen dan kelas kontrol setelah diberikan perlakuan.

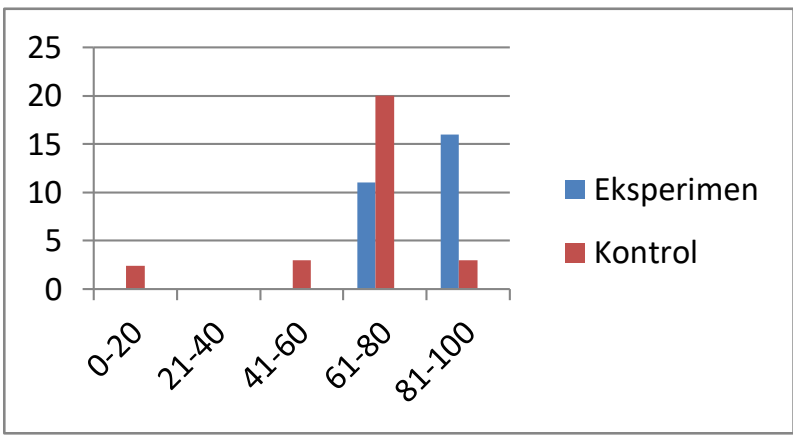

Gambar 2

Diagram Batang Penyebaran Data Skor Penilaian Kemampuan Kerjasama Kelas Eksperimen dan Kelas Kontrol (Posttest) 
Pada setiap indikator dan setiap kelas terdapat perbedaan indikator yang dominan. Kelas eksperimen dengan jumlah 27 siswa pada indikator komunikasi siswa yang dominan 4 siswa, terlihat bahwa masih terdapat beberapa siswa yang masih kurang aktif dalam diskusi kelompok namun masih banyak siswa yang secara inisiatif sendiri menjawab pertanyaan dari guru. pada indikator sumbangan ide terdapat 4 siswa yang dominan, dalam penyampain pendapat siswa masih kurang menjelaskan pendapat tersebut secara logis dan sistematis. Indikator menghargai kontribusi terdapat 3 siswa yang dominan, selama diskusi berjalan terdapat beberapa siswa yang bercanda dengan anggota lain namun tetap berada di kelompok tersebut. Pada indikator mendorong partisispasi terdapat 7 siswa yang mendominasi, terdapat beberapa siswa yang mengajak anggota kelompok untuk bersama-sama dalam menyelesaikan tugas kelompok. Pada indikator tidak mendominasi kelompok terdapat 9 siswa yang mendominasi, tugas yang dikerjakan dalam kelompok diselesaikan secara tepat waktu bahkan lebih awal dari waktu yang telah menjadi kesepakatan. Selain itu terdapat pembagian tugas yang merata setiap anggota kelompok.

Pada kelas kontrol setelah diberikan perlakuan berupa model Group Investigation, terdapat perbedaan yang dilihat dari indikator yang dominan. Indikator komunikasi terlihat dari 26 siswa terdapat 6 siswa yang dominan, selama diskusi berlangsung terdapat beberapa siswa yang aktif berbicara mengenai materi. Pada indikator sumbangan ide terdapat 6 siswa yang dominan, siswa berani memberikan pendapat dengan jelas namun belum mampu menjelaskan secara logis. Selanjutnya di indikator menghargai kontribusi terdapat 8 siswa yang dominan, siswa mampu menghargai siswa lain dengan cara mendengarkan, tidak memotong pembicaran maupun tidak berpindah tempat selama diskusi berjalan. Dari 26 siswa terdapat 5 siswa yang dominan pada indikator mendorong partisispasi, beberapa siswa mampu mengajak siswa lain untuk ikut serta dalam diskusi. Pada indikator tidak mendominasi kelompok terdapat 1 siswa yang mendominasi, didalam kelompok dalam pembagian tugas dilakukan secara tidak merata, dikerjakan hanya oleh beberapa siswa saja.

$$
\text { Deskriptif skor awal kemampuan }
$$
kerjasama menunjukan bahwa rata-rata skor penilaian kemampuan kerjasama pada kelas eksperimen adalah 44,81 dengan skor terendah adalah 32 dan skor tertinggi adalah 54. Setelah diberikan perlakuan berupa pembelajaran terdapat peningkatan pada rata-rata yaitu 83,33 dengan skor terendah 70 dan skor tertinggi adalah 95 . Sedangkan pada kelas kontrol hasil skor awal kemampuan kerjasama memiliki rata-rata 48,46 dengan skor terendah adalah 40 dan skor tertinggi adalah 58. Setelah diberikan perlakuan terdapat peningkatan terlihat dari rata-ratanya adalah 71,50 dengan skor terendah 60 dan skor tertinggi adalah 85. Berikut merupakan table hasil analisis deskriptif skor akhir kemampuan kerjasama siswa.

Tabel 2

Hasil Analisis Deskriptif Skor Akhir Kemampuan Kerjasama

\begin{tabular}{|lr|r|r|r|r|}
\hline \multicolumn{6}{|c|}{ Descriptive Statistics } \\
& N & $\begin{array}{r}\text { Mini } \\
\text { mum }\end{array}$ & $\begin{array}{c}\text { Maxi } \\
\text { mum }\end{array}$ & Mean & $\begin{array}{c}\text { Std. } \\
\text { Deviation }\end{array}$ \\
\hline Eksperimen & 27 & 70 & 95 & 83,33 & 7,731 \\
\hline Kontrol & 26 & 60 & 85 & 71,50 & 7,522 \\
\hline $\begin{array}{l}\text { Valid N } \\
\text { (listwise) }\end{array}$ & 26 & & & & \\
\hline
\end{tabular}

Pada Group Statistic terlihat bahwa untuk kelas eksperimen memiliki rata-rata 83,33 dan kelas kontrol memiliki rata-rata 71,50 , yang artinya penilaian kemampuan kerjasama siswa pada kelas eksperimen lebih tinggi dari kelas kontrol. Tahap selanjutnya hasil posttest di uji prasyarat yaitu uji normalitas dan homogenitas 
yang selanjutnya dapat dilakukan uji beda atau uji t-test. Uji normalitas digunakan untuk mengetahui apakah setiap kelas sebagai objek penelitian mempunyai distribusi data yang normal atau tidak. Data dapat dikatakan berdistribusi normal adalah jika nilai signifikan >0,05. Berikut merupakan hasil uji normalitas skor penilaian kemampuan kerjasama setelah perlakuan (posttest).

Tabel 3

Uji Normalitas Skor Penilaian Kemampuan Kerjasama (Posttest)

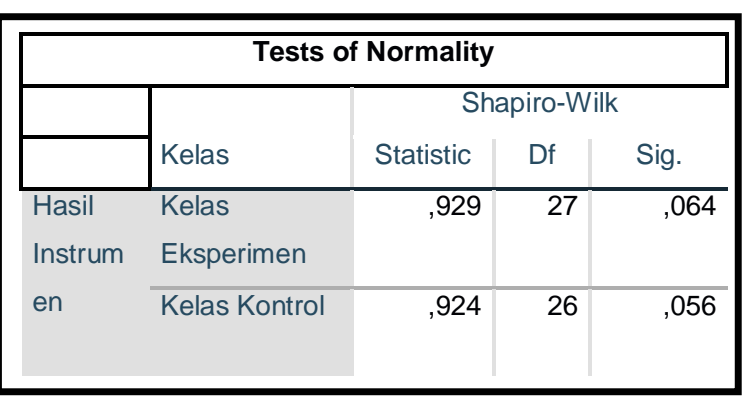

Berdasarkan tabel 3 hasil uji normalitas skor posttest di kelas eksperimen dan kelas kontrol memiliki nilai signifikan diatas 0,05 yang dapat disimpulkan, bahwa data posttest kelas eksperimen dan kelas kontrol bersifat normal.

Setelah dilakukan uji normalitas maka akan diuji homogenitas untuk mengetahui apakah kedua kelompok tersebut homogen atau tidak. Kedua kelompok dikatakan homogen jika nilai signifikan >0,05. Berikut merupakan hasil uji homogenitas skor penilaian kemampuan kerjasama.
Tabel 4

Uji Homogenitas Skor Penilaian Kemampuan Kerjasama (Posttest)

\begin{tabular}{|llr|r|r|r|}
\hline \multicolumn{7}{|c|}{ Test of Homogeneity of Variance } \\
& & $\begin{array}{r}\text { Levene } \\
\text { Statistic }\end{array}$ & df1 & df2 & Sig. \\
\hline $\begin{array}{l}\text { Hasil } \\
\text { Instrum } \\
\text { en }\end{array}$ & Based on Mean &, 301 & 1 & 51 &, 586 \\
\cline { 2 - 7 } & Based on Median &, 120 & 1 & 51 &, 731 \\
\cline { 2 - 6 } & Based on Median &, 120 & 1 & 50,99 &, 731 \\
& $\begin{array}{l}\text { and with adjusted } \\
\text { df }\end{array}$ & & & 9 & \\
\cline { 2 - 6 } & Based on & & & & \\
trimmed mean & & & & \\
\hline
\end{tabular}

Berdasarkan table tabel 3 hasil uji homogenitas skor penilaian kemampuan kerjasama pada kelas eksperimen dan kelas kontrol memiliki nilai signifikan $>0,05$. Sehingga dapat disimpulkan bahwa skor posttest kelas eksperimen dan kelas kontrol bersifat homogen.

Uji Independent Sample T-Test digunakan untuk mengetahui perbedaan signifikansi hasil skor penilaian kemapuan kerjasama pada kelas eksperimen dan kelas kontrol. Dikatakan memiliki perbedaan yang signifikan jika nilai signifikansi lebih kecil dari 0,05 $(<0,05)$. Selanjutnya hasil uji Independent Sampel T-Test digunakan untuk menentukan hipotesi. Uji Independent Sampel TTest dilakukan dengan menggunakan bantuan software SPSS 25.0 for windows. Berikut merupakan hasil uji Independent Sampel T-Test yang disajikan dalam tabel. 
Tabel 4

Uji Independent Sampel T-Test

\section{Independent Samples Test}

\begin{tabular}{|c|c|c|c|c|c|c|c|c|}
\hline & \multicolumn{7}{|c|}{ t-test for Equality of Means } \\
\hline & & & & $\begin{array}{l}\text { Sig. } \\
(2-\end{array}$ & Mean & $\begin{array}{l}\text { Std. } \\
\text { Error }\end{array}$ & $95 \%$ & $\begin{array}{l}\text { e Interval of the } \\
\text { rence }\end{array}$ \\
\hline & & $\mathrm{t}$ & df & $\begin{array}{l}\text { tailed } \\
\text { ) }\end{array}$ & $\begin{array}{l}\text { Differe } \\
\text { nce }\end{array}$ & $\begin{array}{l}\text { Differen } \\
\text { ce }\end{array}$ & $\begin{array}{c}\text { Low } \\
\text { er }\end{array}$ & Upper \\
\hline Kemampua & $\begin{array}{r}\text { Equal } \\
\text { varianc } \\
\mathrm{es} \\
\text { assume } \\
\mathrm{d}\end{array}$ & 5,645 & 51 & ,000 & 5,296 & 11,833 & $\begin{array}{r}7,62 \\
5\end{array}$ & 16,042 \\
\hline $\begin{array}{r}\mathrm{n} \\
\text { Kerjasama }\end{array}$ & $\begin{array}{r}\text { Equal } \\
\text { varianc } \\
\text { es not } \\
\text { assume }\end{array}$ & 5,648 & 50,994 & ,000 & 5,296 & 11,833 & $\begin{array}{r}7.62 \\
7\end{array}$ & 16,040 \\
\hline
\end{tabular}

Terlihat bahwa nilai signifikansi (sig.2tailed) memiliki nilai 0,000 yang memiliki nilai kurang dari 0,05 , sehingga dapat disimpulkan $\mathrm{H}_{\mathrm{o}}$ ditolak dan $\mathrm{H}_{\mathrm{a}}$ diterima. Sehingga dapat disimpulkan bahwa kemampuan kerjasama menggunakan model pembelajaran Problem Based Learning lebih unggul secara signifikan dibandingkan dengan model pembelajaran Group Investigation pada pembelajaran IPA kelas 4 SD Negeri Panjang 03.

Keefektifan model pembelajaran Problem Based Learning dibandingkan model Group Investigation sejalan dengan penelitian yang dilakukan oleh Intan Restu Agustri bahwa setelah menggunakan model PBL dalam pembelajaran terdapat peningkatan yang signifikan terhadap kemampuan kerjasama siswa.

Bertolak belakang dengan penelitian yang dilkukan oleh Dimas Anjar yang menyimpulkan bahwa menggunakan model Group Investigation memberikan dampak hasil kerjasama yang tinggi dibandingkan model Problem Based Learning.

Pembelajaran berbasis masalah adalah pembelajaran yang berkaitan dengan permasalahan dan berhadapan langsung dengan dunia nyata atau kehidupan sehari-hari sehingga dapat merangsang siswa untuk belajar (Kurniasih, 2014: 88). Seperti halnya yang dikatakan oleh (Sanjaya, 2010: 112) bahwa belajar merupakan proses mental yang dialami oleh seseorang, sehingga menyebabkan munculnya perubahan perilaku pada seseorang tersebut. Perilaku yang ingin dilihat disini adalah kemampuan kerjasama siswa. Selain itu, untuk membangun kerjasama yang efektif maka menggunakan diskusi dalam kelompok kecil (Wagaman, 2012: 73).

Hal ini menunjukkan bahwa model Problem Based Learning sesuai dengan pendapat (Rusman, 2016 : 232) menjelaskan bahwa terdapat karakteristik model PBL diantarnya bahwa permasalahan yang diangkat dalam pembelajaran membutuhkan perspektif ganda atau sudut pandang yang berbeda, sehingga dibutuhkan diskusi dan tukar pemikiran di dalam pembelajaran salah satunya melalui pembentukan kelompok. Dikatakan pula bahwa pembelajaran menggunakan model PBL menganggap bahwa sebuah pembelajaran tersebut merupakan kolaboratif, komunikasi, dan kooperatif. Salah satu karakteristik model PBL selanjutnya adalah permasalahan yang diangkat sebagai titik awal dalam melaksanakan pembelajarm, siswa dalam menghadapi permasalahan memiliki penyelesain 
yang berbeda-beda dibutuhkan kerjasama (komunikasi, tukar pikiran dan menghargai) sehingga akan didapat penyelesaian yang tepat. Hal tersebut dapat dilakukan dalam kelompok kecil, seperti halnya yang telah diterapkan oleh $\mathrm{Ni}$ L. Sudewi, I W. Subagia, dan I N. Tika sama seperti yang dilakukan oleh peneliti, pada model PBL siswa di buat dalam kelompok kecil secara heterogen dan siswa dibiasakan untuk menganalisis permasalahan, mengidentifikasi dari permasalahan tersebut, merumuskan hipotesis, mencari solusi, serta mengkomunikasikan strategi pemecahan yang tepat dan mampu menyimpulkan hasil yang tepat. Dalam hal ini diperlukan kerjasama antar siswa dalam kelompok (Sudewi, 2014: 2). Diperkuat dengan pendapat bahwa proses pembelajaran dapat berlangsung jika didalamnya satu dengan yang lain saling terkait atau saling berhubungan (Kristin F, 2017: 91).

Signifikansi keefektifan model Problem Based Learning turut dilatar belakangi oleh kekuatan model sebagaimana yang dijelasakan (Warsono dan Hariyanto, 2014: 152) bahwa model PBL memiliki kekuatan diantaranya: a) melatih siswa sehingga dapat terbiasa menghadapi suatu masalah tidak hanya di kelas namun di kehidupan sehari-hari. b) menumbuhkan rasa solidaritas dan kerjasama dikarenakan terdapat diskusi dalam kelompok maupun teman sekelas. c) menimbulkan keakraban guru dan siswa atau siswa dengan siswa, tidak hanya keakraban tetapi adanya sikap menghargai. d) permasalahan yang muncul terdapat kemungkinan diselesaikan melalui ekperimen dan dapat membiasakan siswa untuk menerapkan metode ekperimen.

Kekuatan dari penelitian ini yaitu 1) Keefektifan model Problem Based Learning dan Group Investigation terhadap kemampuan kerjasama telah dibuktikan melalui penelitian ini.

2) Perlakuan yang diberikan mencangkup pembelajaran tematik, sebagaimana bahwa kurikulum 2013 merupakan pembelajaran yang dilaksanakan secara tematik terpadu. 3) penilaian kemampuan kerjasama dilakukan oleh beberapa observer sehingga setiap siswa dalam kelas terlihat secara jelas kemapuan kerjasama yang dimiliknya. Sedangkan untuk kelemahan dari penelitian ini yaitu terlihat dari hasil uji normalitas bahwa latar belakang kemampuan pada kelas eksperimen dan kontrol sama sehingga kemampuan kerjasama siswa hanya memiliki perbedaan yang tidak terlalu jauh.

\section{SIMPULAN}

Hasil penelitian eksperimen yang telah dilaksanakan untuk mengetahui kemampuan kerjasama siswa melalui penerapan model Group Investigation dan Problem Based Learning pada siswa kelas 4 SD Negeri Panjang 03 Ambarawa pada pembelajaran IPA dengan materi gaya dan macam-macamnya menunjukkan bahwa nilai ratarata kemampuan kerjasama siswa dengan menggunakan model Problem Based Learning pada kelas eksperimen memiliki rata-rata 83,33 lebih tinggi dibandingkan dengan nilai rata-rata kemampuan kerjasama siswa menggunakan model Group Investigation pada kelas kontrol yaitu sebesar 71,50. Dari uji $\mathrm{t}$ dengan Independent Sample $t$ Test diperoleh nilai signifikansi (Si. 2Tailed) ditentukan 0,000 sehingga $0,000<0,05$ sehingga $\mathrm{H}_{\mathrm{o}}$ ditolak dan $\mathrm{H}_{\mathrm{a}}$ diterima. Disimpulkan bahwa kemampuan kerjasama menggunakan model pembelajaran Problem Based Learning lebih unggul secara signifikan dibandingkan dengan model pembelajaran Group Investigation pada pembelajaran IPA kelas 4 SD Negeri Panjang 03, sehingga dapat disimpulkan terdapat perbedaan efektivitas kemampuan kerjasama siswa muatan pelajaraan IPA kelas 4 dengan menggunakan model Problem Based Learning dan Group Investigation SD Negeri Panjang 03 Ambarawa. 
267 Efektivitas penggunaan model PBL dengan model GI terhadap kemampuan kerjasama siswa sekolah dasar-Bernadetha Titis Wulan Sari, Firosakia

\section{DAFTAR PUSTAKA}

Agustri, Intan Restu. 2018. Penerapan Model Problem Based Learning Untuk Meningkatkan Sikap Kerjasama dan Hasil Bejalar Siswa Pada Subtema Keberagaman Budaya Bangsaku. Repository UNPAS.

Anjar, Dimas. 2019. Perbedaan Efektivitas Group Investigation dengan Problem Based Learning Terhadap Kerjasama Siswa Mata Pelajaran IPA Siswa Kelas 5 SD Ggus Joko Tingkir. Jurnal Basicedu.

Fitrianingsih, Tsalatsa. dan Untari. 2019. Keefektifan Model Pembelajaran Group Investigation Terhadap Hasil Belajar Materi Sumber Daya Alam Kelas IV SD Negeri Puri 03. Jurnal Ilmiah Pendidikan dan Pembelajaran.

Huda. 2013. Model-model Pengajaran dan Pembelajaran. Yogyakarta: Pustaka Pelajar.

Kristin, F. 2015. Keefektifan Model Pembelajaran Berbasis Budaya (PBB) Untuk Meningkatkan Hasil Belajar IPS. Jurnal Scholaria.

Kristin, F. 2017. Analisis Model Pembelajaran Discovery Learning dalam Meningkatkan Hasil Belajar Siswa SD. Jurnal Pendidikan Dasar PerKhasa.

Kurniasih, Imas, dan Sani. 2014. Implementasi Kurikulum 2013 Konsep dan Penerapanya. Surabaya: Kata Pena.

Rahayu, Ika. dan Yulistiani, Irna. 2016. Penerapan Model Pembelajaran Problem Based Learning Untuk Meningkatkan Sikap Kerjasama Dan Hasil Belajar Siswa Pada Pembelajaran Tematik di SDN Kencana Indah II. Jurnal Didaktik.

Rosita, Ita. dan Leonard. 2013. Meningkatkan Kerja Sama Siswa Melalui Pembelajaran
Kooperatif Tipe Think Pair Share. Jurnal Ilmiah Pendidikan MIPA

Rusman. 2016. Model-Model Pembelajaran (Mengembangkan Profesionalisme Guru Edisi Kedua). Jakarta: Rajawali Pers.

Samatowa. 2011. Pembelajaran IPA di Sekolah Dasar. Jakarta: Indeks.

Samini. 2012. Pendidikan Karakter. Bandung: PT Remaja Rosdakarya.

Sanjaya, Wina. 2010. Strategi Pembelajaran Berorientasi Standar Proses Pendidikan. Jakarta: Prenada Media Group

Slameto. 2015. Belajar dan Faktor-faktor yang Mempengaruh. Jakarta: PT Renika Cipta.

Sudewi, Ni L., Subagia I W., dan Tika I N. 2014. Studi Komparasi Penggunaan Model Pembelajaran Problem Based Learning (PBL) dan Kooperatif Tipe Group Investigation (GI) Terhadap Hasil Belajar Berdasarkan Taknonomi Bloom. Jurnal Pendidikan dan Pembelajaran IPA Indonesia. 